\title{
Successful Life and Politeness Ethic in Darmalaksita Manuscript by Mangkunegara IV
}

\author{
Endang Tri Winarni ${ }^{1, *}$, Sugit Zulianto ${ }^{2}$ \\ ${ }^{1,2}$ University Centre of Excellence Javanology for Javanese Traditions, Universitas Sebelas Maret, Surakarta, \\ Indonesia \\ *Corresponding author, Email: endang_tw@staff.uns.ac.id
}

\begin{abstract}
Local wisdom in the old Javanese script generally has the values of moral education as a source of learning and guidelines for achieving goals in various aspects of life. Local wisdom in the Javanese script by Mangkunegara IV, especially the Darmalaksita fiber or often referred to as Darmawasita, is very thick with moral education and motivation in achieving life success. This paper aims to describe how to achieve success in life and about the ethics of sociability. The method used is descriptive method, with literature techniques, and documentation. The results showed that the values of moral education in the Javanese text by Mangkunegara IV include individual, social and religious moral values, namely being a perfect human being: tough, noble, good personality, educated and knowledgeable, hardworking, and able to prosper the family. in undergoing household ark. The results of this study can be used as material for oriental character education, in this case Java.
\end{abstract}

Keywords: darmalaksita, Mangkunegara IV, tips for success in life, politeness in socializing

\section{INTRODUCTION}

Kanjeng Gusti Pangeran Adipati Arya Mangkunegara IV (KGPAA Mangkunegara IV) was born on March 3, 1811 (Monday Pahing, 8 Sapar 1738 in Java) died September 2, 1881; He became the ruler of Mangkunegaran (1853-1881), a duchy (small kingdom) founded by KGPAA Mangkunegara I based on the Salatiga Agreement in 1757, (two years after the Giyanti Agreement). After the palihan nagari 'division of labor' and at the same time the succession war ended, it was the renaissance era, an era that gave birth to great poets. They are Yasadipura I, Yasadipura II, Ranggawarsita, Paku Buwana IV, and Mangkunegara IV. The succession period in Surakarta lasted for approximately 120 years, (from 1757 to the death of Ranggawarsita in 1873 or the death of Mangkunegara IV in 1881).

The literary work of the great poet is a documentation of culture and local wisdom which contains various aspects of the past life. Local wisdom that contains the values of moral education, in this case is piwulang 'teaching' literary type, namely literary works containing various kinds of teachings. Piwulang in Serat Darmawasita is a literary work that has a more democratic mindset. His teachings are not only aimed at men but also women, especially the teachings about the right to achieve success in life. Other piwulang such as Wulang Wanita (teachings of women) (serat Condrorini, serat wulang putri, serat wanita dyah utama, etc.) generally teach about women as individuals and women as wives, while in Serat Darmalaksita women are positioned the same as men to achieve goals and success. in career.

The problems in this research are: (1) what keys to a successful life are contained in the Darmalaksito text; and (2) how is the attitude and politeness to socialize in the Darmalaksito text? Therefore, the purpose of this research is to answer these problems.

\section{THEORETICAL AND LITERATURE STUDY}

What is often referred to as local wisdom, local genius or more precisely local knowledge, is defined as a set of practices that are usually determined by rules that are accepted clearly, vaguely, a ritual or symbolic nature, which wants to instill values and norms. - certain behavior norms through repetition, which automatically implies continuity with the past [1] [11]. Local wisdom is usually manifested as a system of philosophy, values, norms, customary law, 
ethics, social institutions, belief systems through ceremonies.

Local wisdom is defined as a "tool" of knowledge and practical practices that can be used to solve problems faced in a good and correct way [2]. Furthermore, local wisdom (local genius, local wisdom) (Quaritch Wales in Poespowardojo, [3] [4]) formulates that local genius is "the sum of the cultural characteristics which the vast majority of a people have in common. as a result of their experiences in early life. The main ideas contained in the definition include (i) cultural characteristics, (ii) a group of people as the owner of the culture, and (iii) life experiences that produce these cultural characteristics. Local genius [3] has resistance to elements that come from outside and is able to develop for the future.

People's personalities are determined by the strengths and abilities of the local genius in dealing with external forces. If the local genius is lost or destroyed the nationality's personality will fade away. The factors that become the learning and learning of local wisdom have a strategic position, such as (i) local wisdom is an inherent identity shaping from birth, (ii) local wisdom is not alienation to the owner, (iii) community emotional involvement in the appreciation of local wisdom is strong, (iv) learning local wisdom does not require coercion, (v) local wisdom can foster self-esteem and self-confidence, (vi) local wisdom can increase the dignity of the nation and state.

Oman Fathurahman [5] says that manuscripts are a form of cultural treasures, which contain written texts regarding various information, thoughts, knowledge, history, customs and behavior of past societies. Compared with non-written forms of material cultural heritage in Indonesia, such as temples, palaces and mosques; The number of cultural relics in the form of manuscripts is clearly much larger [6]. Manuscripts, which have so far been neglected, and only get the attention of certain groups of people, especially philologists and librarians, actually have a very broad meaning and dimension because they are a product and a long tradition involving various cultural attitudes of society in this period. certain [7].

\section{RESEARCH METHODS}

According to Moh. Nazir [8] what is meant by research design is all the processes required in planning and conducting research. Suharsini Arikunto [9] research design includes the following processes, namely: (1) identification and selection of research problems, (2) selection of research conceptual framework and relationship with previous studies, (3) formulating problems, including specification of the objectives and scope of the problem, (4) choosing the variety and research strategy, (5) determining the variables and data sources, (6) selecting the sampling procedures and techniques used, (7) developing data collection instruments and techniques, (8) making code, editing and processing data, (9) analyzing data, and (10) making research reports.

Variety and research strategies are determined by several things, namely: (1) the method of implementation, (2) objectives, (3) approach, (4) science, (5) place, (6) variables, (7) data analysis model.

The way it is implemented is to describe using a variety of action research (action research) or (participatory observation). This is the reason, because classical literature as a cultural document of the people in Surakarta strongly maintains its local wisdom. In what ways can the people of Surakarta take advantage of the local wisdom in Javanese which is "unique" that they have adhered to so far in order to see a more open future (not closed, educated, follow reasonable socioeconomic developments) without reducing their positive traditions (honesty, simplicity, loyalty). Based on the research location, this research is a fieldwork research, so there is no need to give treatment to the object of research as in experimental research.

The variables used in this research are current variables, especially local wisdom in the text of Serat Darmalaksita, the behavior of Javanese tradition, rejection of Javanese tradition in general, and cultural reasons. Because the data is in the form of qualitative data (verbal data and practical data based on local wisdom), the data analysis uses single case data analysis in the form of qualitative descriptive presentation.

\section{DISCUSSION}

Kanjeng Gusti Pangeran Adipati Arya Mangkunegara IV (KGPAA Mangkunegara IV) was born on March 3, 1811, died September 2, 1881; He became the ruler of Mangkunegaran (1853-1881), a duchy (small kingdom) founded by KGPAA Mangkunegara I based on the Salatiga Agreement in 1757, (two years after the Giyanti Agreement). After the palihan nagari 'division of labor' and at the same time the succession war ended, it was the renaissance era, an era that gave birth to great poets. They are Yasadipura I, Yasadipura II, Ranggawarsita, Paku Buwana IV, and Mangkunegara IV. The succession period in Surakarta lasted for approximately 120 years, (from 1757 to the death of Ranggawarsita in 1873 or the death of Mangkunegara IV in 1881).

The literary work of the great poet is a cultural documentation in the form of Javanese script 
(handwritten and Javanese script) and is local wisdom that contains various aspects of the past life. One type of Javanese manuscript is piwulang 'teachings', which is a literary work that contains various kinds of teachings. Piwulang in Serat Darmawasita is not only intended for men but also women. Wulang Wanita (serat Condrorini, serat wulang putri, serat wanita dyah utama, etc.) generally teaches about women as individuals and women as wives, while in Serat Darmawasita women are positioned the same as men to achieve goals and success in their careers. Mangkunegara IV's work entitled Darmalaksita or Darmawasita was chosen as this object because the teachings in this work are democratic in nature, this work places men and women having the same rank and position in achieving a good life. This equivalence can be seen from stanza 1, verse 1 Dhandhanggula as follows:

/1/ mrih sarkara pamardining siwi | pinurwaka dènira manitra | nujwari Salasa Wage | tri wêlas sasi Mulud | kasanga Dal sangkalèng warsi | winêling anêngaa | sariranta iku | mring iki wasitaningwang | dhawuh marang putrèngsun jalu lan èstri | padha angèstokêna ||

Artinya: Hopefully sweet in educating children / starting writing, on Selasa (Tuesday) Wage, 13 Mulud, Mangsa Sanga (9), Taun Dal with candrasengkala, winêling anêngaa sariranta iku, this message, for boys and girls, do it //

Serat Darmalaksita by Mangkunegara IV was created on Tuesday wage, 13 Mulud Dal, 1807 A.J (wineling anengaa sariranta iku) or Monday Wage, March 18, 1878 A.D. The fiber is in the form of a macapat tembang, consisting of 3 stanzas, the first pupuh of the dhandhanggula 12 stanzas, the second pupuh of the kinanti 10 stanzas and the third pupuh of the mijil 19 stanzas. Darmalaksita fiber is also commonly referred to as Darmawasita fiber. Both have the same meaning, namely advice / teachings of virtue / goodness regarding the obligations of life and human actions to achieve success. The teaching can be divided into 4 parts; namely the teachings of astagina (eight faedahs), teachings of social attitudes and ethics, teachings about seriousness and work professionalism, and special teachings for women or wulang putri. In the case of astagina teachings it implies the obligations and responsibilities of the younger generation to achieve bright dreams / futures. This teaching is aimed at both men and women, that they must be able to live independently (without relying on the wealth of their parents), tough, have noble character, have skills, have good careers, are tenacious, persistent, hard-working, and have a good personality. The Astagina teachings are complemented by teachings of social attitudes and ethics and sincerity of work. Mangkunegara IV stated that these three things are the keys to a successful life. If this teaching is properly pursued and applied in his life, he will certainly be able to achieve his goals, become a perfect human being: noble, independent, tough, good personality, educated and knowledgeable, good at socializing, big-spirited, hard-working, and able to prosper the family) and prosperous life. The teachings in wulang putri teach about the attitudes and roles of women to achieve happiness in the household.

\section{a. Teachings of Tips for Life Success: Astagina}

According to Mangkunegara IV, to achieve success in life the teachings of astagina (eight benefits) as mentioned in the Dhandhanggula pupuh, verses 35 , are as follows:

13/Yeka mangka srananing dumadi/tumanduke marang saniskara/ manungsa apa kajate/ sinembadan sakayun/yen dumunung mring wolung warni/ ingaran astagina/ iku tegesipun/ wolung pedah tumrapira/ marang janma margane mrih sandhang buktil kang dhihin winicaral

14/ panggaotan gêlaring pambudi | warna-warna sakaconggahira | nut ing jaman kalakone | rigên ping kalihipun |dadi pamrih marang pakolih | katri gêmi garapnya | margane mrih cukup | ping pat nastiti pamriksa | iku dadi margane wêruh ing pasthi | lima wruh ing petungan ||

15/ watêk adoh mring butuh saari| kaping nênêm tabêri têtanya| ngundhakkên marang kawruhe|ping pitu nyêgah kayun | pêpenginan kang tanpa kardi| tan boros maring arta | sugih watêkipun | ping wolu nêmên ing sêja | watêkira sarwa glis ingkang kinapti | yèn bisa kang mangkana ||

Thus the teaching of tips for success in life in Astagina (eight benefits) can be described as follows:

1) Panggaotan /permanent job: people must work in accordance with their respective fields of expertise / professionalism,

2) Rigen: skilled and able to find solutions when faced with difficulties / problems.

3) Gemi: frugal and careful in managing the budget, clever in managing finances so that his life needs are always fulfilled.

4) Nastiti : Careful and thorough in making policies.

5) Wruh petungan: effective and efficient, able to pay attention and consider the situation

6) Taberi tatanya : learn a lot by asking to expand knowledge 
7) Nyegah kayun : prevent and control unwholesome desires

8) Nemening seja : persistent, strong willed, determined, serious, hardworking

The astagina teaching for the first point is more emphasized and underlined the importance of working to earn an income without relying on the wealth of parents as happened before. So you must be able to live independently. People who do not work, do not heed advice, and like to be lazy are people who are despicable, lose confidence, are frustrated, and have a life in vain. This is explained in the first stanza, verse 7, Dhandhanggula as follows:

77/ luwih lara larane kang ati | nora kaya wong tininggal arta $\mid$ kang wus ilang piandêle | lipure mung yèn turu | lamun tangi sungkawa malih | yaiku ukumira | wong nglirwakkên tuduh | ingkang aran budi daya $\mid$ têmah papa asor dènira dumadi | tan amor lan sasama $\|$

Meaning: // 'a pain that hurts more / is not like a person who has no money / has lost his pride / his entertainment is just sleeping / waking up sad again / that's the law / people do not heed advice / who are called always trying / ultimately despicable their life cannot live (have enough) like each other//

18/kaduwunge saya angranuhi/ sanalika kadi suduk jiwa/enget ing kaluputane/yen kena putraning sun/aja kadi kang wus winuni/ dumeh wus darbe sira/panci pancen cukup/becik linawan gaota/kang supaya kayumanan ing dumadi/panulat mring sangsarall

Meaning: / 'being disappointed is getting worse / immediately is like committing suicide / remembering his mistake / if possible / not like everyone already has / just because everyone has enough / it's better to fight it by working / to be safe and prosperous / that's an example miserable//

Mangkunegara IV added that to achieve a successful life, one of the ways to take is to have a permanent job, in accordance with the field he is engaged in. When you already have a permanent job, there are surefire tips so that your career can develop and progress. The tips are: must be diligent at work, diligent, tenacious, persistent, full of enthusiasm, never give up, and be professional. In pupuh kinanthi stanzas $1-5$, the attitude of seriousness of work is explained as follows:

1) Sregep: attitude of diligent work with full enthusiasm and discipline,

2) pethel: work with sincerity,
3) tegen : resilient, unyielding, steadfast and not bored,

4) wekel : diligent and wholeheartedly,

5) pangati-ati : attitude of caution,

\section{b. The Teaching of Politeness:}

Astagina teachings, which are the key to success in achieving a good future, need to be complemented and perfected by teaching attitudes and ethics to get along in the family, work environment, and society. This teaching emphasizes the attitude of politeness (in getting along both politely in attitude and in speaking) and an attitude of determination that defends the truth. This teaching attitude of politeness is found in the dhandhanggula stanzas 9-12 as follows:

a) manising netra luruh : gentle eyesight, does not create the impression of resistance and avoids misunderstanding.

b) trapsila ing tata: good manners, good at placing oneself, to avoid anger

c) wicara alus: soft-spoken, makes the interlocutor happy and strengthens this brotherhood and also avoids feeling offended.

d) Wong manut caraning bangsa: follow / adapt to customs and procedures wherever we are, this will expand the relationship.

e) andhap asor: humble nature is far from pride

f) meneng: don't talk too much that is not important, do not brag, talk as necessary,

g) prasaja: simplicity of life, natural appearance, not exaggeration, avoiding the envy of the viewer.

h) tepa salira: good at placing themselves

i) enget: always be on the lookout to avoid harm

j) olah batin: always take care for personal safety

k) kelakuan becik: good personality

l) catur upaya (four kinds of effort):

i. aniru kang becik : imitate and follow the good things

ii. nurut kang bener : follow the right

iii. nggugu kang nyata : believe in what's real

iv. milih kang pakolih: select the useful

\section{CONCLUSION}

Local wisdom in Javanese manuscripts by Mangkunegara IV, especially in the Serat Darmalaksita or Darmawasita, is a type of piwulang where the contents of the teaching place the role of women to have the same degree as men, especially in terms of attaining education, careers, and a future that is in line with their dreams.

To achieve success in life, people need to pay attention to Astagina teachings and ethics of 
politeness. According to Mangkunegara IV, people who are considered successful have tough, noble character, good personality, educated and knowledgeable, sociable, big-spirited, hardworking, and can prosper the family.

\section{AUTHORS' CONTRIBUTIONS}

All authors contribute to the content of the paper from the beginning to the end of writing the paper.

\section{ACKNOWLEDGMENTS}

Acknowledgements and appreciation to University Centre of Excellence Javanologi for Javanese Traditions, Universitas Sebelas Maret.

\section{REFERENCES}

[1] M, Slamet, Pemberdayaan Masyarakat. Dalam Membetuk Pola Perilaku Manusia Pembangunan. Disunting oleh Ida Yustina dan Adjat Sudradjat. Bogor: IPB Press. 2003.

[2] H.S. Ahimsa-Putra, Makalah Pelatihan. Paradigma, Epistemologi Dan Metode Ilmu Sosial Budaya. Sebuah Pemetaan. Yogyakarta, Antropologi Budaya Fakultas Ilmu Budaya Universitas Gadjah Mada, 2007

[3] S. Poespowardojo, Kepribadian Budaya Bangsa (Local Genius). Dalam Ayatrohaedi, (Penyunting), "Pengertian Local Genius dan Relevansinya dalam Modernisasi”, Selected
Reading, hlm. 15-24. Jakarta: PT. Dunia Pustaka Jaya. 1986

[4] F.X. Rahyono, Kearifan Budaya Dalam Kata, Cet. Pertama, Jakarta: Penerbit Wedatama Widya Sastra, 2009

[5] O. Fathurahman, Filologi Indonesia, Teori dan Metode, Jakarta: Kencana Prenadamedia Group, 2015

[6] A. Ikram, Filologia Nusantara. Jakarta: PT. Dunia Pustaka Jaya, 1997

[7] Baried, S. Baroroh, dkk, Pengantar Teori Filologi. Yogyakarta: BPPF, Seksi Filologi, Fakultas Sastra, UGM, 1994

[8] M. Nazir, Metodologi Penelitian, Jakarta: Ghalia Indonesia, 1988.

[9] A. Suharsini, Prosedur Penelitian: Suatu Pendekatan Praktek, Jakarta: Rineka Cipta, 1998.

[10] KGPAA Mangkunegara IV, Serat Piwulang Warni-warni. ND.

[11] Haniah, S.T. Widodo, S. Suwandi, K. Saddhono, B. Mohamad. Investigating the traditional proverbs and their impact on cultural identity and communication: Lessons from the Madurese community, Journal of Advanced Research in Dynamical \& Control Systems 11(5), 846-857. 2019 